\title{
Condensed Matter Division
}

\section{Call for nominations :}

The next election for the Section Boards of the Condensed Matter Division will be held in April/May 1977. Six members for each Board have to be elected for a three-year term. Members of the Board may be reelected, subject to the provision that at least three previously elected members shall retire at each election. No member of the Board shall serve for more than six consecutive years.

At present, each of the five Sections (Low Temperature Physics, Macromolecular Physics, Magnetism, Metal Physics and Semiconductor and Insulator Physics) consists of six members elected in 1974 and between three and six coopted members. The Section for Surface and Interface Physics is in the state of formation and is at the moment run by a Steering Committee.

The existing Boards and the Steering Committee of the Surface and Interface Physics Section have prepared the following lists of candidates for publication in Europhysics News and for circulation among the $\mathrm{Na}$ tional Societies, members $4 \mathrm{~b}$. (The names of the 1974 elected Board members are marked with one asterisk, those of coopted Board members with two asterisks.)

\section{Low Temperature Physics}

* W.J. Huiskamp, Leiden, The Netherlands

* T. Lindquist, Uppsala, Sweden

** C. Rizzuto, Genoa, Italy

* R.S. Safrata, Rez, Czechoslovakia

** Yu.V. Sharvin, Moscow, USSR

** J. Souletie, Grenoble, France

\section{Macromolecular Physics}

* E.W. Fischer, Mainz, Fed. Rep. Germany

* W. Holzmüller, Leipzig, German Dem. Rep.

H.H. Kausch, Lausanne, Switzerland

A.J. Pennings, Groningen, The Netherlands

* I.M. Ward, Leeds, Great Britain G. Zerbi, Milan, Italy

\section{Magnetism}

* G. Busch, Zurich, Switzerland

** W. Haubenreisser, Jena, German Dem. Rep.

** A. Hubert, Erlangen, Fed. Rep. Germany

V. Kambersky, Prague, Czechoslovakia

* R. Pauthenet, Grenoble, France

* E.P. Wohlfarth, London, Great Britain

\section{Metal Physics}

* P. Averbuch, Grenoble, France G. Caglioti, Milan, Italy

R.M.J. Cotteril, Lyngby, Denmark D.J. Fabian, Strathclyde, Great Britain

* J. Muller, Geneva, Switzerland

* W. Schilling, Jülich, Fed. Rep. Germany

\section{Semiconductor and Insulator} Physics

F.W. Ainger, Caswell, Great

Britain

Zh. I. Alferov, Leningrad, USSR

* M. Balkanski, Paris, France

G. Chiarotti, Rome, Italy

* P. Grosse, Aachen, Fed. Rep. Germany

* C. Hilsum, Malvern, Great Britain

\section{Surface and Interface Physics}

G. Ertle, Munich, F.R.G.

B. Feuerbacher, Noordwijk, The Netherlands

C.J. Todd, Martlesham Heath,

Great Britain

$\mathrm{H}$. van Hove, Heverlee, Belgium

$\mathrm{T}$. van Oostrom, Eindhoven, The

Netherlands

C. Weissmantel, Karl-Marx-

Stadt, German Dem. Rep.

Further candidates can be nominated by the National Societies, members $4 \mathrm{~b}$, and by Individual Ordinary Members, members $4 \mathrm{a}$ and $4 \mathrm{c}$, who are Section members. Such members of the Sections, at least six in number for any one nomination, may nominate other candidates having obtained their previous consent. The nominations should reach the

\section{EPS Secretariat}

P.O. Box 39

$\mathrm{CH}-1213$ Petit-Lancy 2

by March 31, 1977. Some Section Boards in fact urge the members to propose nominations in addition to the ones listed above.

A ballot by mail will be organized by the EPS Secretariat in April/May 1977. The names of the elected Board members will then be published in Europhysics News.

The newly elected Boards will then constitute themselves and elect their Chairmen from amongst the members of the Board. One representative of each Section, who shall normally be its Chairman, will be a member of the Board of the Condensed Matter Division. It is expected that the new CMD Board will constitute itself during the Third CMD Conference in Leeds, UK, July 26-29, 1977.

\section{Europhysics Journals}

The latest journals accepted as Europhysics Journals are Physics in Technology and Zeitschrift für Physik, where the recognition will appear as from volumes 281 (Part A) and 27 (Part B).

Zeitschrift für Physik is a scientific journal published in two parts. Part A has, since vol. 272, specialized in atomic physics and nuclear physics, while Part B has, since vol. 20, when it was combined with Physics of Condensed Matter, dealt with the physics of condensed mater and general physics (quantum optics, statistical physics, non-equilibrium and co-operative phenomena). Each Part can be ordered separately from Springer-Verlag, of Berlin, Heidelberg and New York.

As a contrast, Physics in Techno$\log y$ is a magazine rather than a reference journal. It is meant to be read, by individual physicists and engineers, and this is reflected in its informal style of presentation. It is interdisciplinary and covers the whole spectrum of the applications of physics in technology and engineering. It is published by the Institute of Physics, London and Bristol, and Individual Ordinary Members of the European Physical Society are entitled to subscribe to the magazine at reduced rates (see Europhysics News, 7 (1976) 9, Sept., p. 8).

The Nouvelle Revue d'Optique has changed its title from Jan. 1, 1977 to Journal of Optics. The publishers strongly recommend authors to submit their papers from now on in English.

\section{Member Societies}

The Acting Secretary of the Austrian Physical Society is now Dr. $\mathrm{H}$. Kirchmayr whose address is : c/o Institut für Experimentalphysik, Karlplatz 13, A - 1040 Vienna.

The new President of the Roland Eötvös Physical Society is Prof. G. Marx who succeeds Prof. G. Szigeti, elected Honorary President.

Editor : E.N. Shaw

Editorial Board:

G. J. Béné, B. Glovanninl, M. Guenin,

B. Hauck, J. Muller, S. Newman

All correspondance to:

Editor, EUROPHYSICS NEWS,

European Physical Society,

P.O. Box 39

CH-1213 Petit-Lancy 2

Phone: Geneva 931132

Switzerland.

Published by the European Physical Soclety

Printed by: Ed. Cherix et Fllanosa SA CH-1260 Nyon, Switzerland 